\title{
Investigation on Mechanical Strength of Concrete Using Steel Bottle Caps as Fiber
}

\author{
S. Rahman \\ Department of Civil Engineering, Port City International University, Bangladesh
}

Copyright $\odot 2019$ by authors, all rights reserved. Authors agree that this article remains permanently open access under the terms of the Creative Commons Attribution License 4.0 International License

\begin{abstract}
Metals used as cap for containers preserve liquids in the bottles, but the dumping of caps particularly soft drink bottle caps are harmful for the environment. On the other hand, concrete has low tensile strength and to offset this problem some fiber like material can be added to concrete to increase its tensile strength. Hence, an effort was made in the present investigation to study the influence of addition of waste materials like soft drink bottle caps at a dosage of $0.5 \%, 1 \%$ and $1.5 \%$, of total weight of concrete as fiber. In this study, caps were cut into strips of size of 3 $\mathrm{mm}$ width and $10 \mathrm{~mm}$ length. Experimental investigation was carried out adding bottle caps in concrete and tests were carried out as per recommended procedures by relevant codes. The experimental values such as compressive strength and split tensile strength were found to be increased. The most improved compressive strength and split tensile strength were found for $1 \%$ bottle cap fiber. The strengths were increased by maximum $22.98 \%$ and $23.14 \%$ respectively.
\end{abstract}

Keywords Concrete, Bottle Caps, Steel Fiber, Compressive Strength, Split Tensile Strength

\section{Introduction}

Concrete being a brittle material which has low tensile strength and low strain capacity, as a result, the mechanical behaviour of concrete is critically influenced by crack propagation (Behera et al. 2015). Introduction of fibers in discrete form in plain or reinforced concrete may provide a better solution (Romualdi et al. 1963). Experimental studies proved that fibers improve the mechanical properties of concrete such as flexural strength, compressive strength, tensile strength, creep behavior, impact resistance and toughness (Shukla, 2011). Murali et.al (2012) observed that soft drink bottle caps reinforced blocks exhibited an increase in flexural strength of concrete by $25.88 \%$. Venu et al. (2011) investigated the impact of cement bags waste on concrete, and found that when the percentage of fiber in concrete was 3.5\% it's compressive and tensile strength increased considerably. Kandasamy et al. (2011) added $0.5 \%$ by volume of polythene (domestic waste polythene bags) fiber to concrete and the compressive strength increased by $5.12 \%, 3.84 \%$ and $1.63 \%$ respectively.

This study intends to study the impact of steel bottle cap fibers of $0.5 \%, 1 \%$ and $1.5 \%$ with a constant size of $3 \mathrm{~mm} \mathrm{x}$ $10 \mathrm{~mm}$ on improvement of concrete compressive and split tensile strength. The bottle caps that were used in this study to prepare fibers were collected from local shop in Khulshi, Chittagong, Bangladesh as waste materials (Fig. 1).

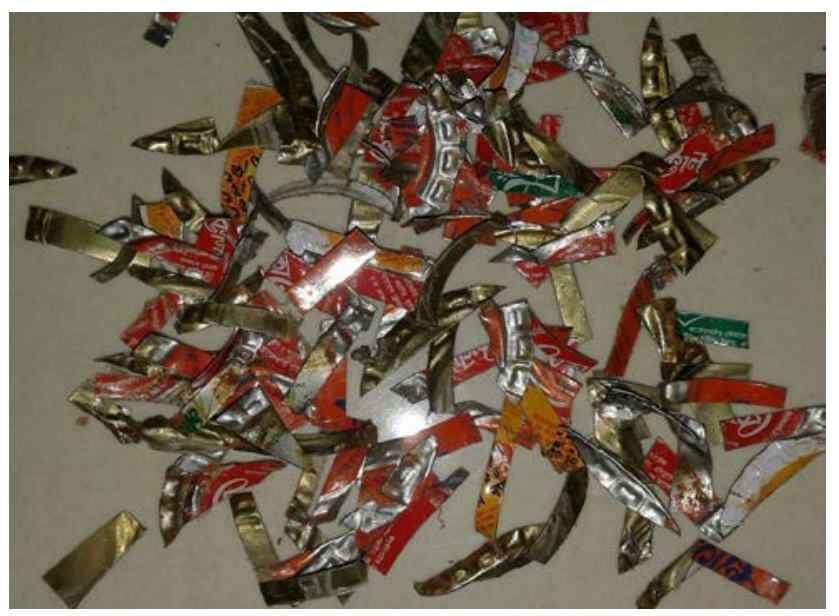

Figure 1. Steel Bottle Caps Fiber

\section{Materials and Methods}

\subsection{Materials}

Ordinary Portland cement was used for casting of concrete. Specific gravity of cement was tested. Locally available sand collected from Sylhet, Bangladesh was used as fine aggregate (FA). Crushed stones of $19 \mathrm{~mm}$ 
downgrade were used as coarse aggregates (CA). All the tests conducted on the materials are mentioned in Table 1 with the results.

Table 1. Test results of different materials

\begin{tabular}{|c|c|c|}
\hline Materials & Name of tests & Results \\
\hline \multirow{2}{*}{ Cement } & $\begin{array}{c}\text { Specific gravity (ASTM } \\
\text { C188-16) }\end{array}$ & 3.31 \\
\hline \multirow{4}{*}{ Sand } & $\begin{array}{c}\text { Specific gravity (ASTM } \\
\text { C128-15) }\end{array}$ & 2.21 \\
\cline { 2 - 3 } & $\begin{array}{c}\text { Absorption capacity (ASTM } \\
\text { C128-15) }\end{array}$ & $18.85 \%$ \\
\cline { 2 - 3 } & $\begin{array}{c}\text { Gradation (ASTM C778-13) } \\
\text { Coarse } \\
\text { aggregates }\end{array}$ & $\begin{array}{c}\text { Fineness } \\
\text { Modulus }=2.76\end{array}$ \\
\cline { 2 - 3 } & $\begin{array}{c}\text { Specific gravity (ASTM } \\
\text { C127-15) }\end{array}$ & 2.39 \\
\cline { 2 - 3 } & $\begin{array}{c}\text { Dry rodded unit weight } \\
\text { (ASTM C29-C29M-17) }\end{array}$ & $11.8 \%$ \\
\cline { 2 - 3 } & $\begin{array}{c}\text { Gradation (ASTM } \\
\text { C33-C33M-16e1) }\end{array}$ & $\begin{array}{c}\text { Fineness } \\
\text { Modulus }=5.02\end{array}$ \\
\hline
\end{tabular}

\subsection{Mix Design}

From the results of materials tests, ACI mix design was conducted targeting 3000 psi compressive strength and the ratio among cement (C), FA and CA and water-cement ratio $(\mathrm{W} / \mathrm{C})$ were found as given in Table 2 . The slump value was found as $28 \mathrm{~mm}$.

Table 2. Mix design results

\begin{tabular}{|c|c|}
\hline C: FA: CA & $1: 2.5: 3.31$ \\
\hline W/C & 0.49 \\
\hline
\end{tabular}

\subsection{Casting and Curing}

The fibers were mixed with concrete as shown in Fig. 2. Total 12 cubes and 12 cylinders were casted (Fig. 3) for compressive strength and split tensile strength tests respectively. The amounts of steel bottle cap fibers were maintained as $0.5 \%, 1 \%$ and $1.5 \%$ of weight of concrete. The sizes of fibers were also maintained as $3 \mathrm{~mm}$ width and $10 \mathrm{~mm}$ length.

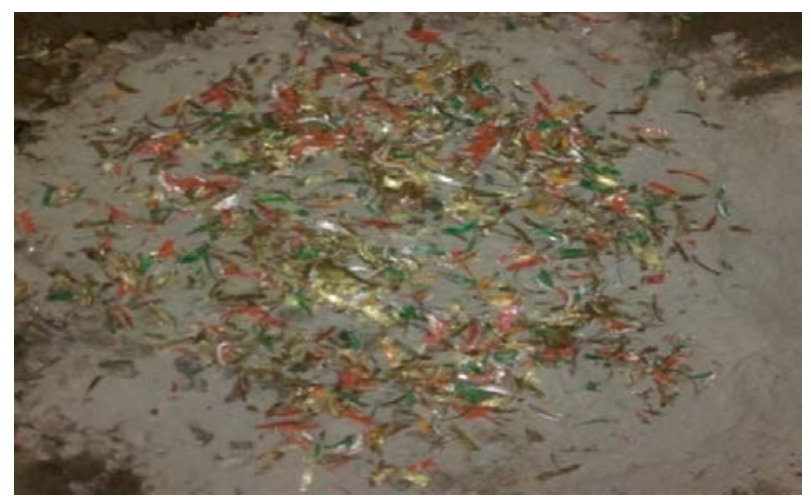

Figure 2. Mixing of fibers

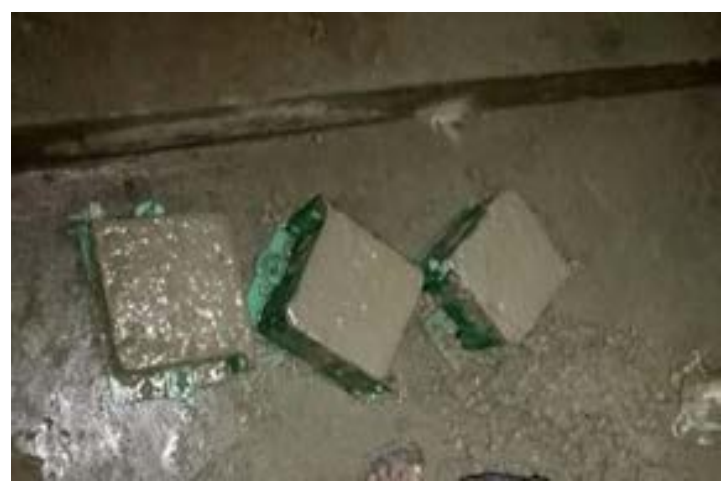

Figure 3. Concrete casting

\subsection{Compressive and Split Tensile Strength Test}

The cubes were tested for compressive strength (ASTM C39-C39M-17) and the cylinders were tested for split tensile strength (ASTM C496-C496M-11) with respective ages of curing as 7, 14 and 28 days. Universal Testing Machine (UTM) of capacity of $1000 \mathrm{KN}$ was used for both compressive strength and split tensile strength tests as shown in Fig. 4 and Fig. 5.

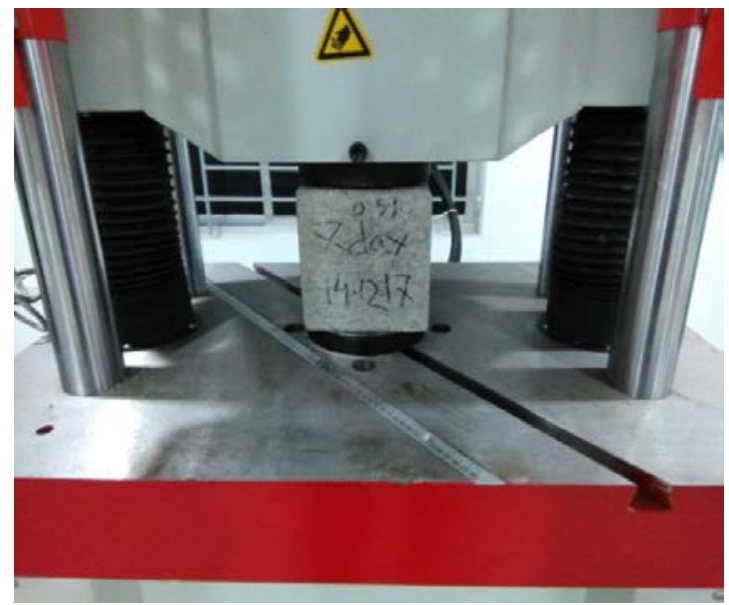

Figure 4. Compressive strength test of concrete cube

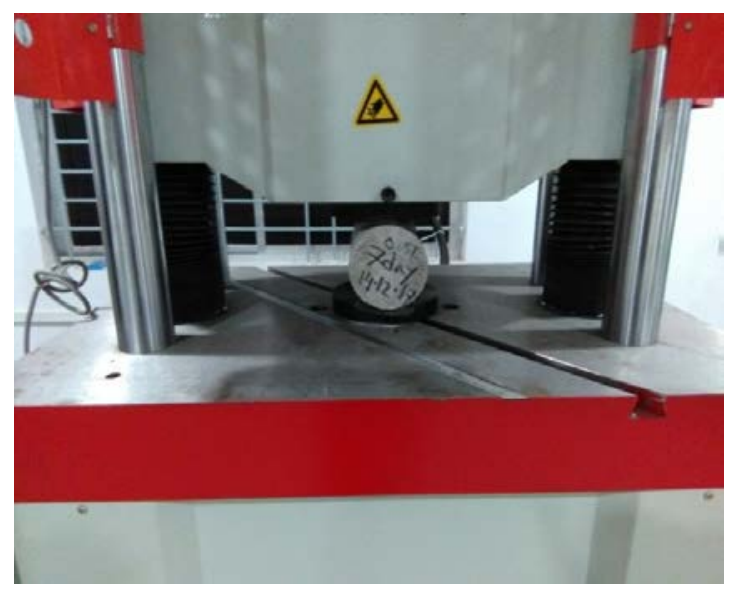

Figure 5. Split tensile strength test of concrete cylinder 


\section{Result and Discussion}

\subsection{Result}

The results of the tests on concrete samples are given below.

- $\quad$ For $0.5 \%$ bottle cap fiber, the compressive strength was improved by $5.4 \%$ to $21.8 \%$ and the split tensile strength was improved by $0.25 \%$ to $9.83 \%$ compared to plain concrete in all curing periods.

- $\quad$ For $1 \%$ bottle cap fiber, the improvement was in between $12.25 \%$ to $22.98 \%$ for compressive strength and $6.62 \%$ to $23.14 \%$ for split tensile strength.

- Also for $1.5 \%$ bottle cap fiber, the improvement was reduced than $1 \%$ fiber and the improvement was in between $4.56 \%$ to $7.18 \%$ for compressive strength and $0.35 \%$ to $6.45 \%$ for split tensile strength compared to plain concrete in all curing periods.

\subsection{Discussion}

From Fig. 6 and 7, it can be seen that, both the compressive and split tensile strength were improved in all curing periods for all percentages of steel fibers. The improvement was gradually increasing from $0.5 \%$ fibrous concrete to $1 \%$ fibrous concrete, but again the improvement on $1.5 \%$ fibrous concrete was reduced compared to $1 \%$ fibrous concrete. Overall, the most improved compressive and split tensile strength were found for $1 \%$ fibrous concrete.

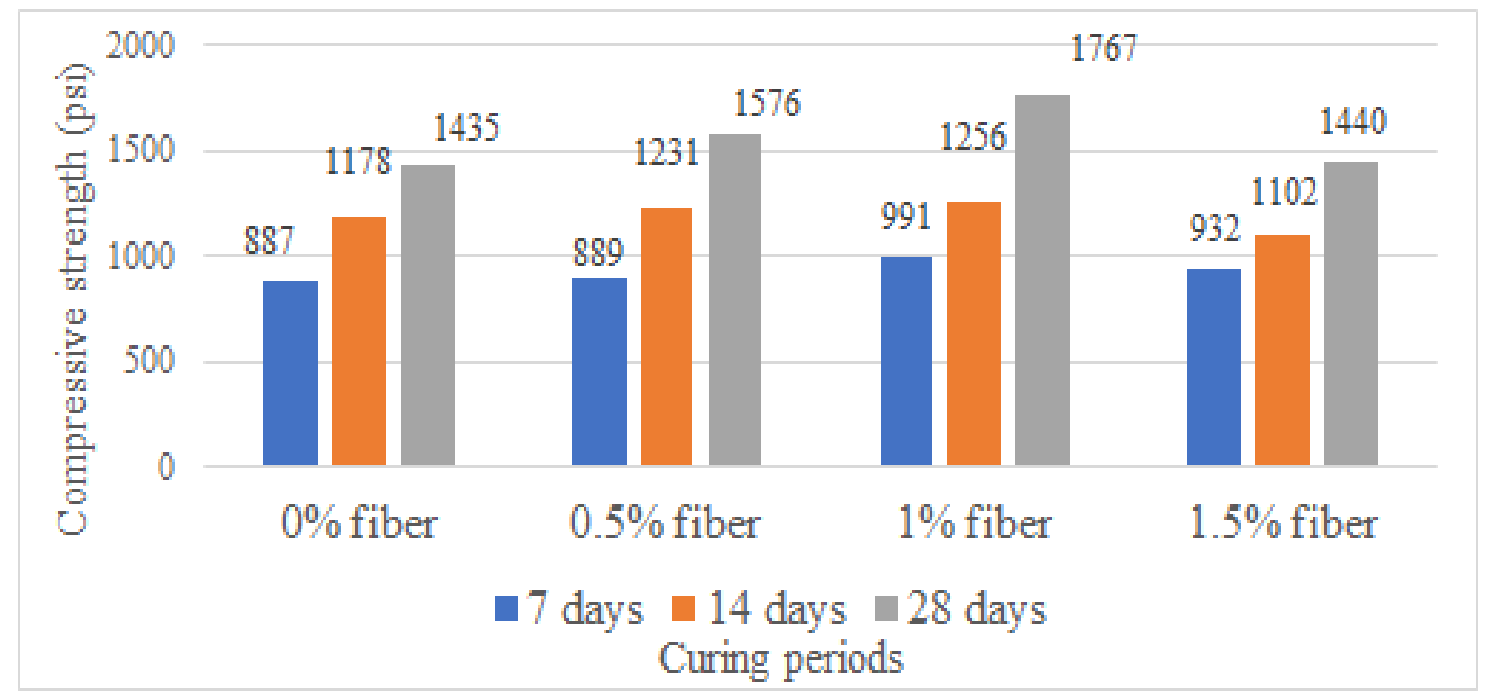

Figure 6. Comparison between compressive strength for plain concrete and concrete with $0.5 \%, 1 \%$ and $1.5 \%$ steel bottle cap fibers with respect to curing periods

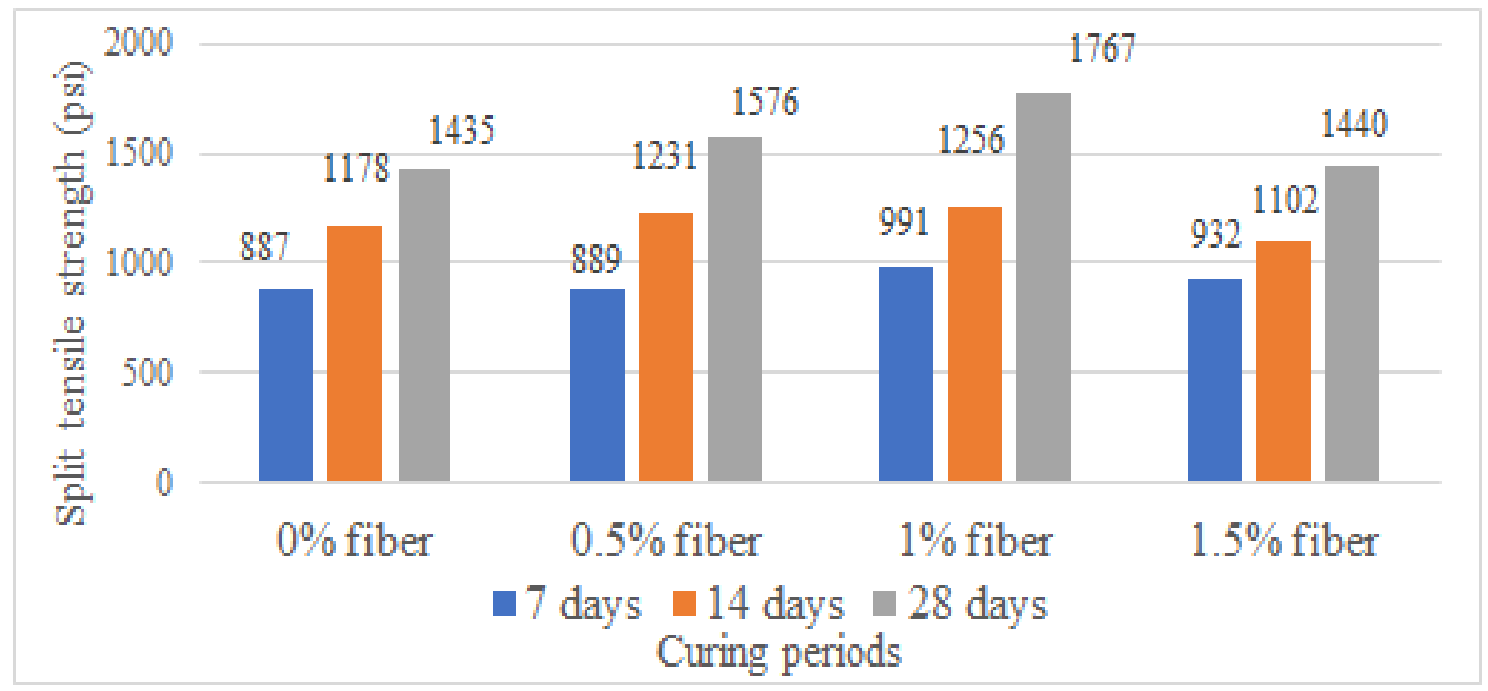

Figure 7. Comparison between split tensile strength for plain concrete and concrete with $0.5 \%, 1 \%$ and $1.5 \%$ steel bottle cap fibers with respect to curing periods 


\section{Conclusions}

A simple experimental study was conducted on concrete with addition of steel bottle cap fibers. The strengths were improved by adding the fibers. But surplus mixing of steel fibers reduced the strength. It happened due to over mixing of fiber with respect to other materials in concrete. So, steel fibers if used in adequate quantity can improve the mechanical strength of concrete.

\section{Acknowledgements}

The authors would like to acknowledge Department of Civil Engineering, Port City International University, Chittagong, Bangladesh for giving the opportunity for using the Engineering Materials Laboratory facilities for the experimental works.

\section{REFERENCES}

[1] ASTM C29-C29M-17 Standard test method for bulk density ("unit weight”) and voids in aggregate.

[2] ASTM C33-C33M-16e1 Standard Specification for Concrete Aggregates.

[3] ASTM C39-C39M-17 Standard test method for compressive strength of cylindrical concrete specimens.

[4] ASTM C127-15 Standard test method for density, relative density (specific gravity), and absorption of coarse aggregate.
[5] ASTM C128-15 Standard test method for relative density (specific gravity) and absorption of fine aggregate.

[6] ASTM C188-16 Standard test method for density of hydraulic cement.

[7] ASTM C496-C496M-11 Standard test method for splitting tensile strength of cylindrical concrete specimens.

[8] ASTM C778-13 Standard specifications for standard sand.

[9] Behera, G., C. and Behera, R., K. (2015), 'Increase in strength of concrete by using bottle caps' International Research Journal of Engineering and Technology, Vol. 2, No. 3, pp. 1937-1942.

[10] Kandasamy, R. and Murugesan, R. (2011), 'Fiber reinforced concrete using domestic waste plastics as fibres' Journal of Engineering and Applied Sciences, Vol. 6, No. 3, pp. 75-82.

[11] Murali, C., M., Vardhan, R., V., Prabu, Z., Mohammed, T., Arif, T. and Suresh, T. (2012), 'Experimental investigation on fibre reinforced concrete using waste' International Journal of Engineering Research and Applications, Vol. 2, No. 2, pp. 278-283.

[12] Romualdi, J., P. and Batson, G., B. (1963), 'Mechanics of Crack Arrest in Concrete', Journal of the Engineering Mechanics Division' Journal of the Engineering Mechanics Division, ASCE, Vol. 89, No. 3, pp. 147-168.

[13] Shukla, M. (2011), 'Behaviour of reinforced concrete beams with steel fibres under flexural loading' International Journal of Earth Sciences and Engineering, Vol. 4, No. 6, pp. 843-846.

[14] Venu, M. and Neelakanteswara, R. P. (2011), 'Strength characteristics of concrete using solid waste, an experimental investigation' International Journal of Earth Sciences and Engineering, Vol. 4, No. 6, pp. 937-940. 